\title{
Onsite studies of phosphate compounds application for treatment of clayish soils in a railway bed
}

\author{
Victor Ganchits ${ }^{1, *}$, Evgeny Chernyaev ${ }^{1}$, and Victoria Chernyaeva ${ }^{1}$ \\ ${ }^{1}$ Emperor Alexander I St.Petersburg State Transport University, Moscovsky prospect 9, St. \\ Petersburg, 190031, Russia
}

\begin{abstract}
The article presents results of field studies dealing with strengthening clayishsoilsin a ground railway bed using phosphoric acid compounds in a DC electrical field. The authors performed comparison of deformability indicators obtained to those for soil treated by an alternative method using classical formulation based on calcium chloride. Modulus of deformation for soil treated with $\mathrm{CaCl}_{2}$-based electrolyte increased 1.3 times, and reached $19.5 \mathrm{MPa}$, modulus of deformation for soil treated with electrolyte based on $\mathrm{Zn}\left(\mathrm{H}_{3} \mathrm{PO}_{4}\right)_{2}$ grewby a factor of 2.4 , and reached 34.8 $\mathrm{MPa}$. The paper shows the main engineering and process parameters of operations performed for altering the properties of clayish soils in a ground railway bed. Duration of soil treatment using the electrolyte based on calcium chloride was 27 days, while for the phosphate electrolyte it was 14 days. Power consumption was $10,800 \mathrm{kWh}$ and 5,600 kWh, respectively.
\end{abstract}

\section{Introduction}

It is known that electrochemical treatment [1-4] is considered as one of efficient methods for improving physical and mechanical properties of cohesive soils with a filtration rate lower than $0.5 \mathrm{~m} /$ day. The method consists in that, along with subjecting the soil being improved to the action of DC current, some specific electrolytes are introduced into the soil through the electrodes. In the process, new cementing substances are synthesized in the microaggregates contact area and/or on the particles surface, the substances including both new compounds produced by chemical reactions and components of finely dispersed mineral particles. As a result of various physical and chemical processes in the soil involving the electrolyte components, the soil is dehydrated, the finely dispersed fraction is coagulated in the electrode areas, the chemical composition of the absorbed complex is changed, and other phenomena occurleading to alteration of the initial soil properties. The above-listed processes and reactions promote an intensive change in physical and chemical properties of initial clayish soil transforming its performance to reach the indicators comparable with construction soil.

During laboratory studies, electrolyte compounds were produced based on orthophosphoric acid with addition of zinc oxide [6,7].

\footnotetext{
*Corresponding author: lumina1993@mail.ru
} 
- The laboratory tests demonstrated that maximal soil strength and uniformity of its improvement in the inter-electrode zone is achieved by adding a $5 \%$ zinc oxide with electrolyte density of $1.12 \mathrm{~g} / \mathrm{cm} 3$.

- Higher salt concentration doesn't result in any notably greater strength of soil in the intermediate and cathode zones. The highest uniformity of soil improvement is reached by adding a $5 \% \mathrm{ZnO}$.

- The best uniformity and soil samples improvement quality was obtained at the voltage gradient of $1 \mathrm{~V} / \mathrm{cm}$.

- The highest strength of $0.89 \mathrm{MPa}$ in the anode zone and uniform soil improvement was reached using electrolyte with density of $1.12 \mathrm{~g} / \mathrm{cm} 3$. The mineral composition of a clay soil has low impact on the electrolyte efficiency.

- The soil strength intense increase in cathode and intermediate zones is noted for the first 100 hours of treatment, and then the process slowly goes down. Stable water-resistance of soil in the cathode zone is reached after 100-150 hours of treatment

- The study showed that phosphate electrolyte, compared to other electrolyte types used, provides the highest soil improvement strength for the clay soils having small filtration rates (below $0.005 \mathrm{~m} /$ day).

In order to verify their operability and efficiency experimentally, it was required to conduct field studies on an experimental section of an operating ground railway bed.

\section{Experimental study}

The purpose of the onsite studies was assessing the possibility of practical application of electrochemical treatment of clayish soils in a ground railway bed with phosphate electrolyte, and comparing the resultsto those obtained witha classic electrolyte based on calcium chloride.

As an experimental item, a section of a ground railway bed of railway line of ... direction was selected.

Specifications of item under study:

railway bed design -embankment 9.5 mbuilt in 1913;

a culvert is laid in footing of the embankment, 6.0 indiameter, having no defects.

Figure 1 shows the strengthening section layout

As a result of a change in performance of the railway track (an increase in axial and running loads),the experimental section showed deformations of the railway bed, which manifested themselves as regular seasonal depressions of the tracksuperstructure, which affected safety of the transportation process and, therefore, the throughput of the railway line section. In order to ensure reliable performance of the embankment, it was required to perform a package of activities for reinforcing soils of the railway bed. Analysis of properties of the railway bed soil in the experimental section resulted in determining its properties:

heavy silty clay loam;

plasticity index was 0.15 ;

moisture content of clay loam in spring was 0.24 ;

moisture content on yield limit boundary was 0.34 ;

moisture content on rolling-out limitboundary was 0.19 . 


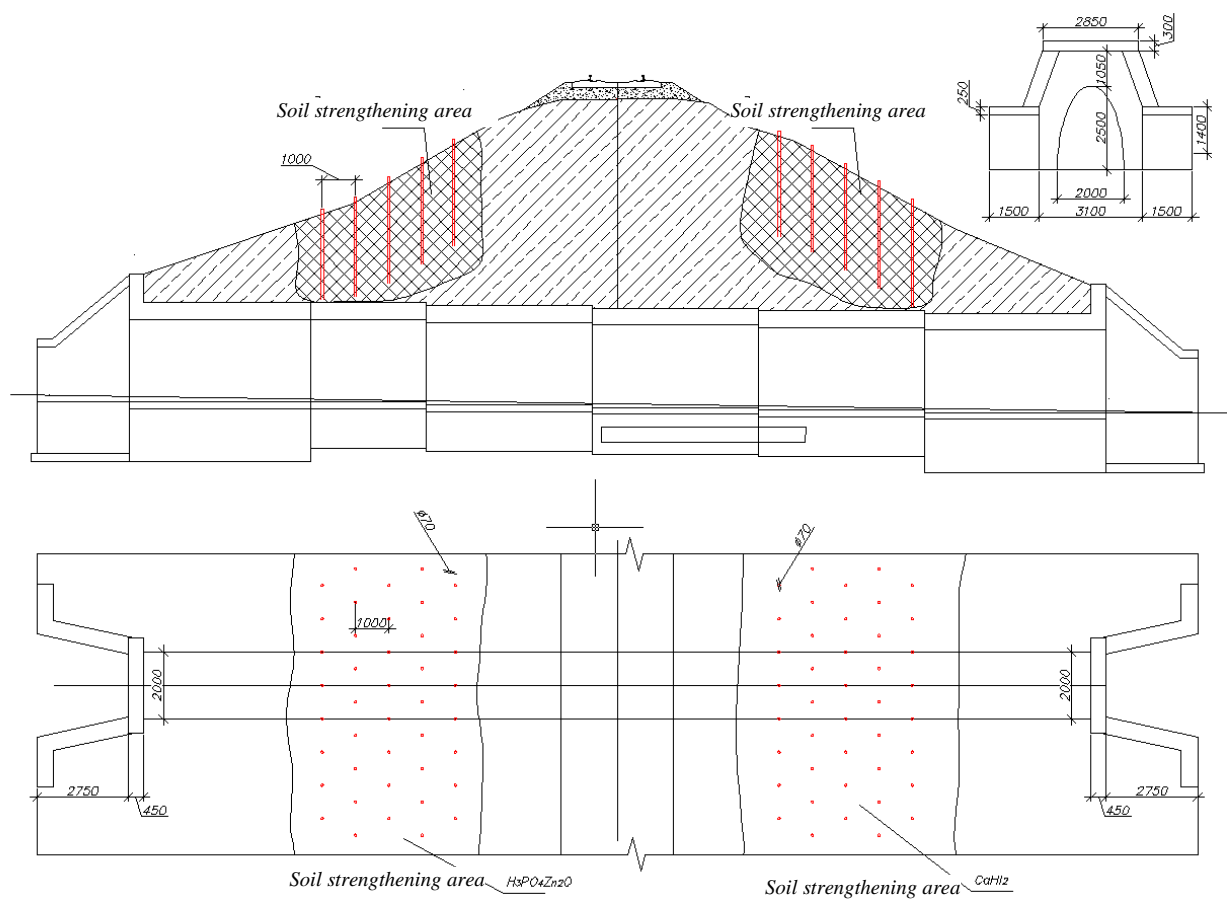

Fig. 1. Railway bed soil strengthening section layout.

As for the grain composition, dusty particles predominate in clay loam. Physical and chemical properties of the soil are given in Table 1 .

Table 1. Physical and mechanical properties of soils on experimental section.

\begin{tabular}{|c|c|c|c|c|c|c|c|c|c|c|c|c|}
\hline \multirow[b]{2}{*}{ Soil } & \multirow[b]{2}{*}{ 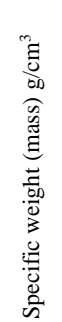 } & \multirow[b]{2}{*}{ 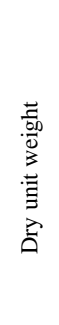 } & \multirow[b]{2}{*}{ 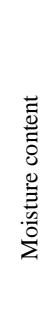 } & \multicolumn{2}{|c|}{ Plasticity } & \multirow[b]{2}{*}{ 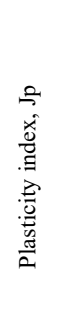 } & \multicolumn{6}{|c|}{ Grain size distribution } \\
\hline & & & & 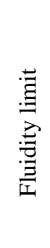 & 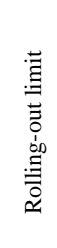 & & 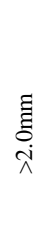 & 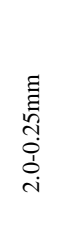 & 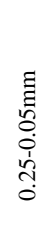 & $\begin{array}{l}\overline{0} \\
0 \\
1 \\
0 \\
0 \\
0\end{array}$ & $\begin{array}{l}\text { ô } \\
0 \\
0 \\
0 \\
0 \\
0\end{array}$ & $\begin{array}{l}\text { ठे } \\
\stackrel{\leftrightarrow}{\mathrm{v}}\end{array}$ \\
\hline $\begin{array}{l}\text { Heavy } \\
\text { silty clay } \\
\text { loam }\end{array}$ & 2.70 & 1.79 & 0.24 & 034 & 0.19 & 0.15 & 2.1 & 11.2 & 11.1 & 15.8 & 30.7 & 29.1 \\
\hline
\end{tabular}

As an experimental application, it was decided to conduct electrochemical treatment of soil to a depth of 2.6-2.8 $\mathrm{m}$ that allows increasing the bearing capacity of the railway bed as result of an increase in strength of component soils. Based on preliminary calculations and simulation of the soil treatment process, steel pipes of $70 \mathrm{mmin}$ diameter were used as electrodes. Total length of the experimental soil treatment section was $40 \mathrm{~m}$ (10 mon either sideof the pipe axis). One section $(20 \mathrm{~m})$ was treated with calcium chloride solution, while phosphoric acid with $\mathrm{ZnO}$ as electrolyte was used for treating the other section $(20 \mathrm{~m})$. Electrolyte density was $1.12 \mathrm{~g} / \mathrm{cm} 3$, zinc oxide concentration was $5 \%$. Chemical composition of the soil subjected to electrochemical treatment is shown in Table 2. 
Table 2. Chemical composition of soil (silicate analysis).

\begin{tabular}{|c|c|c|c|c|c|}
\hline \multirow{2}{*}{ Soil } & \multicolumn{5}{|c|}{ in \% Nand absolutely dry weight } \\
\cline { 2 - 6 } & $\mathrm{SIO}_{2}$ & $\mathrm{Fe}_{2} \mathrm{O}_{3}$ & $\mathrm{Al}_{2} \mathrm{O}_{3}$ & $\mathrm{CaO}$ & $\mathrm{MgO}$ \\
\hline Heavy silty clay loam & 66.33 & 7.45 & 15.2 & 1.14 & 1.61 \\
\hline
\end{tabular}

\section{Operating process}

Electrodes made of steel pipes, $70 \mathrm{mmin}$ diameter, were driven on the sides of the railway bed and partially on embankment slope in 3 rows in checkerboard order at $90-100 \mathrm{~cm}$ from one another; in total, 232electrodes, each $260-280 \mathrm{~cm}$ long, were fabricated.

An electric network was installed according to the detailed design for electrochemical treatment of clayish soil. The network installation consisted in connection of all electrodes and laying a trunk cable. The electric network was made of steel wire, 6 mmin diameter, joined by electric welding directly to the electrodes. Direct current at 90-100 A was supplied via trunk cables to the electrodes 24 hours a day.

Duration of soil treatment using electrolyte based on calcium chloride was 27 days, and using phosphate electrolyte 14 days. Power consumption was $10.800 \mathrm{kWh}$ and $5.600 \mathrm{kWh}$, respectively. Basic technical and process parameters are presented in Table 3.

Table 3. Basic technical and process parameters of soil electrochemical strengthening on experimental section.

\begin{tabular}{|l|c|c|}
\hline \multicolumn{1}{|c|}{ Basic indicators } & $\begin{array}{c}\text { Section treated with } \\
\text { electrolyte based on } \mathrm{CaCl}_{2}\end{array}$ & $\begin{array}{c}\text { Section treated with phosphate } \\
\text { electrolyte } \mathrm{Zn}_{3}\left(\mathrm{H}_{3} \mathrm{PO}_{4}\right)_{2}\end{array}$ \\
\hline $\begin{array}{l}\text { Length of strengthening } \\
\text { section, m }\end{array}$ & 40 & 40 \\
\hline $\begin{array}{l}\text { Total amount of soil } \\
\text { strengthened, m }\end{array}$ & 324 & 300 \\
\hline Distance between electrodes, m & 0.9 & 1.0 \\
\hline Voltage gradient, V/cm & 1.0 & 5600 \\
\hline $\begin{array}{l}\text { Amount of power consumed, } \\
\text { kWh }\end{array}$ & 10,800 & 14 \\
\hline $\begin{array}{l}\text { Total time soil electrochemical } \\
\text { treatment, days }\end{array}$ & 27 & 650 \\
\hline Electrolyte consumption, L & 950 & \\
\hline
\end{tabular}

In 9 months, on completion of electrochemical treatment, soil samples were taken from the strengthened body. From results of the sample studies, physical and mechanical properties of the soil were determined. The results are shown in Table 4.

Table 4. Physical and mechanical properties of soil after treatment.

\begin{tabular}{|l|c|c|c|}
\hline $\begin{array}{l}\text { Physical and mechanical } \\
\text { properties }\end{array}$ & $\begin{array}{c}\text { Soil before } \\
\text { treatment }\end{array}$ & $\begin{array}{c}\text { Soiltreated with } \\
\mathrm{CaCl}_{2}\end{array}$ & $\begin{array}{c}\text { Soil treated with phosphate } \\
\text { electrolyte } \mathrm{Zn}(\mathrm{H} 3 \mathrm{PO} 4) 2\end{array}$ \\
\hline Adhesion, S MPa & 0.014 & 0.024 & 0.042 \\
\hline $\begin{array}{l}\text { Internal friction angle, } \\
\text { deg. }\end{array}$ & 22 & 21 & 24 \\
\hline $\begin{array}{l}\text { Modulus of deformation, } \\
\mathrm{MPa}\end{array}$ & 14.7 & 19.5 & 34.8 \\
\hline
\end{tabular}

As a result of laboratory experiments an ortho-phosphoric acid electrolyte was selected. When used in electrochemical treatment this electrolyte allowed achieving an average clay 
soil improvement of up to $0.7 \mathrm{MPa}$. At that, the strength of cathode zone is $77 \%$ of that of the anode zone. The results are provided in Fig. 2.

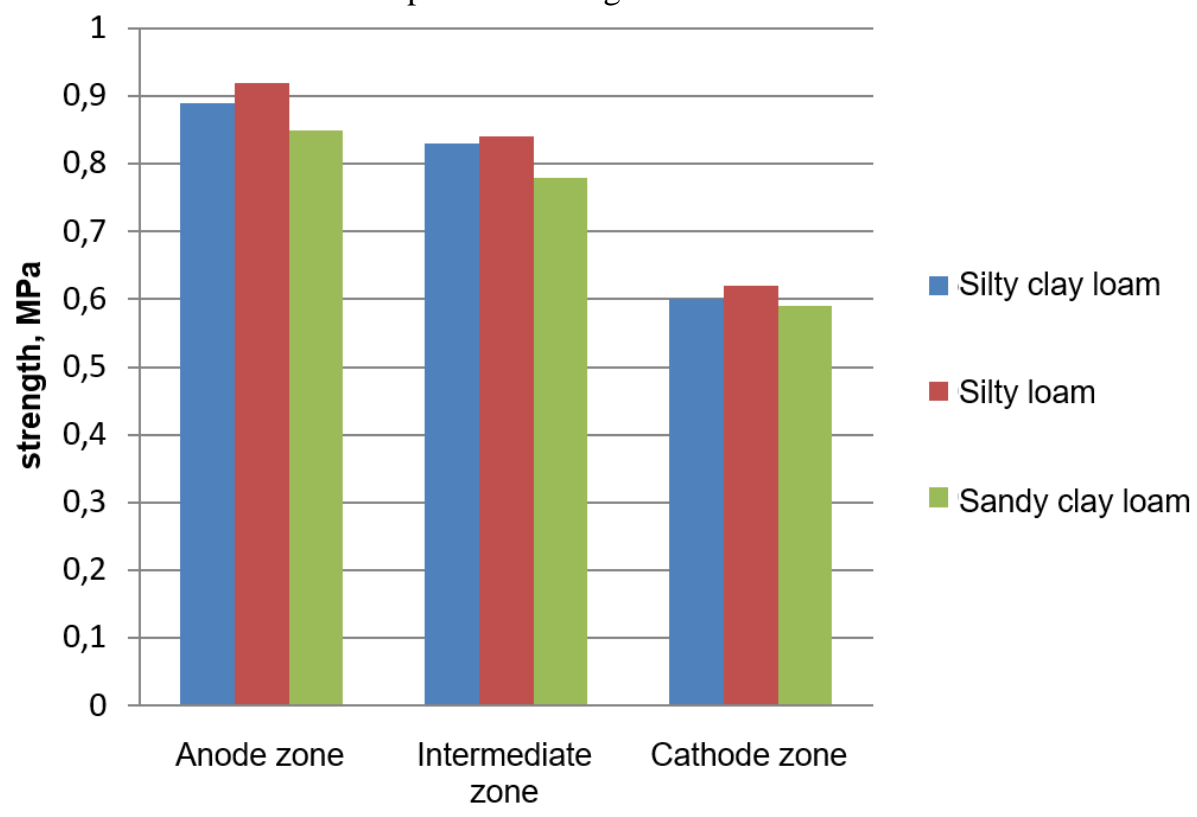

Fig. 2. Soil strength versus its physical and mechanical properties and mineralogy upon electrochemical treatment.

\section{Conclusion}

The onsite studies performed have shown that electrochemical treatment of clayish soil makes it possible to increase its strength characteristics significantly. Modulus of deformation for soil treated with $\mathrm{CaCl} 2$-based electrolyte increased 1.3 times and reached 19.5 $\mathrm{MPa}$, while modulus of deformation for soil treated with electrolyte based on $\mathrm{Zn}(\mathrm{H} 3 \mathrm{PO} 4) 2 \mathrm{grew}$ by a factor of 2.4 and reached $34.8 \mathrm{MPa}$.

Maximum strength and uniformity of soil strengthening in the inter-electrode area is provided using electrolyte based on $\mathrm{Zn}(\mathrm{H} 3 \mathrm{PO} 4) 2$. Physical and mechanical properties of clayish soils are almost two times higher than the results obtained by processing the same soil using electrolyte based on $\mathrm{CaCl} 2$.

Duration of soil treatment using electrolyte based on calcium chloride was 27 days, and using phosphate electrolyte 14 days. Power consumption was 10,800 kWh and 5,600 kWh, respectively.

Railway reinforcement process using electrochemical treatment with electrolytes based on $\mathrm{Zn}(\mathrm{H} 3 \mathrm{PO} 4) 2$ permitted conducting reconstruction of the section without interruption of train traffic.

\section{References}

1. P. Rebinder, Structural and mechanical properties of argillaceous rocks and the present day concepts in physics and chemistry of colloids. Transactions of meeting on geotechnicalproperties of rocks and their research methods (USSR Academy of Sciences, Moscow) 
2. A. Rachmasyah, Soil improvement with electroosmosis method research report toray foundation unpublished (2002)

3. G.N. Zhinkin, Soil improvement by electrochemical method in construction (Stroyizdat, Leningrad)

4. A. Rachmansyah, Y. Zaika, Model Test Perbaikan Tanah Dengan Metode Injeksi Elektrokimia Konferensi Teknik Sipil (Denpasar Bali) (2010)

5. G.N. Zhinkin, K.K. Sergeyenkova, On some chemical processes occurring in clayish soils being exposed to direct current (Transactions of Meeting on theoretical foundations of engineering amelioration of soil MGU Moscow)

6. V. Ganchits, State- of- the- art technologies in the railway transport and industry (Khabarovsk) 3, 178-181 (2003)

7. V. Ganchits, V. Chernyaeva, Procedia Engineering 189, 519-524 (2017) 